Scientific Journal. ISSN 2595-9433

Volume 3, Number 2, Article n. 2, July/December

D.O.I. http://dx.doi.org/10.35418/2526-4117/v3n2a2

Received: 02/13/2021 - Accepted: 05/25/2021

\title{
BAYESIAN INFERENCE AND PREDICTION APPLIED TO THE POSITIONING OF WHEAT YIELD GROWN IN SOUTHERN BRAZIL
}

\section{Ricardo de Oliveira Schneider ${ }^{1}$, (D) Ivan Ricardo Carvalho ${ }^{1 *}$, (D) Vinícius} Jardel Szareski², (D) Kassiana Kehl'3 , (D) Alexandre Moscarelli Levien³, (D) José Antonio Gonzalez da Silva ${ }^{1}$, (D) Danieli Jacoboski Hutra ${ }^{1}$, (D) Velci Queiróz de Souza $^{4}$, (D) Francine Lautenchleger ${ }^{5}$, (D) Murilo Vieira Loro ${ }^{1}$

1 Universidade Regional do Noroeste do Estado do Rio Grande do Sul, Ijuí, RS, Brazil;

2 SLC Agrícola, Cristalina, GO, Brazil;

3 Fundação Pró-Sementes, Passo Fundo, RS, Brazil;

4 Unversidade Federal do Pampa, São Gabriel, RS, Brazil;

5 Universidade do Centro-Oeste, Guarapuava, PR, Brazil.

* Corresponding author: Ivan Ricardo Carvalho (carvalho.irc@gmail.com).

\begin{abstract}
The best genotype aimed at a favorable environment, biometric alternatives should be applied with clarity to recomend which are the cultivars specific to the macro and micro regions. This work aims to estimate and predict the strategic positioning of wheat genotypes in the triticultural environments of Rio Grande do Sul, using fixed linear, mixed linear and bayesian models. The experimental design used was randomized blocks organized in a factorial scheme, with four crop seasons $(2013,2014,2015$, and 2016), three repetitions x nine growing environments. The AMMI and GGE adaptability and stability models were applied to the three statistical scenarios, defining that scenario I represents the estimates obtained by the fixed linear model, scenario II expresses the estimates and predictions obtained by the mixed linear model and scenario III shows the probabilistic predictions obtained by the Bayesian inference. Estimates of variance components and genetic parameters for wheat grain yield in the state of Rio Grande do Sul are expressed by $15 \%$ due to the inherent genetic effects of selecting the best genotype. The growing environments Vacaria - RS, São Gabriel - RS and Cachoeira do Sul - RS Season II revealed the greatest genetic contributions to maximize wheat grain yield regardless of the crop season. The mixed linear model allows the formation of a macroenvironment composed by the São Gabriel - RS and São Luiz Gonzaga - RS environments. Regardless of the model used, the highest grain yields were obtained through the ORS 1402, LG Oro, and Jadeíte 11 genotypes.
\end{abstract}

Keywords: Triticum aestivum L., frequentist and probabilistic statistics, fixed, random and probabilistic models, food security, sustainable development. 


\section{Introduction}

Wheat (Triticum aestivum L.) is one of the oldest and most used crops by man. It is considered one of the main cereals in the world and in Brazil, being fundamental for human and animal nutrition (Pereira et al., 2017). In the food industry, the offer of high nutritional quality, gluten with the ability to form elastic-extensible masses with water absorption potentiates the production of noodles, breads, cakes, cookies, among other derivatives (Szareski et al., 2017).

Currently, the aim is to increase productivity, however, there are multiple factors that influence this aspect, such as climatic conditions, physical and chemical quality of the soil, appropriate choice of genotype, agroclimatic risk zoning, management techniques, sowing speed, and the depth of seed placement are practices that require some caution. Seed quality as an indirect factor takes into account the obtaining of crops with uniformity, free of pathogens and other species, improving management conditions and, consequently, enhancing the implantation of the crop (Santos et al., 2018).

As it is an autogamous species benefited by cleistogamy, it requires for breeding practices the genetic recombination of elite cultivars and other sources of germplasm that are essential for the genetic improvement of the crop (Carvalho et al., 2008). A consolidated breeding program is based on the phases of goal definition, formation of germplasm banks and crosses directed to obtain F1 plants and segregating populations, as well as identification of superior families for the attributes of agronomic interest.

The changes expressed by the phenotype are due to the genetic constitutions intrinsic to the characteristics of each genotype of wheat, however, the environment makes a major contribution to these manifestations, whereas the same genotype can express contrasting phenotypes due to changes in the growing environment and/or contrast of characteristics of each environment. These modifications are called genotype $\mathrm{x}$ environment interaction, which represents the differential response of at least two genotypes grown in different environments, these are classified as simple or complex according to the degree of effects they cause on phenotypic expression (Ribeiro et al., 2008).

For the proper strategic positioning of the best genotype aimed at a favorable environment, biometric alternatives that recommend with certainty and clarity which are the cultivars specific to the macro and micro regions of Rio Grande do Sul should be employed, so that, then, not only the breeder evidences gains in positioning, but the grower has the counterpart of the maximum yield and responses that the genetic potential of the cultivar can provide.

There are many biometric strategies used in the genetic improvement of wheat to estimate the coefficients and rank the best genotypes and environments, minimizing positioning errors. In this context, any method used to estimate adaptability and stability must be supported by the concept of the ideal genotype. For Eberhart and Russel (1966), a genotype considered to be excellent must have high average yield, have productive stability, respond to the improvement of favorable environments and even in unfavorable environments respond with advantage.

Adaptability refers to the ability of genotypes to respond to the stimulus of the environment, that is, it refers to their ability to advantageously take advantage of variations in the environment (Nascimento et al., 2010). While stability refers to the ability of genotypes to express highly predictable behavior, due to the environmental stimulus, Eberhart and Russel (1966) and Mariotti et al. (1976). To be able to position a variety, it must be successful under different environmental conditions, with yield and stability.

The crop has great phenotypic plasticity and numerous genotypes available, therefore, the bottleneck of this activity is to position the genotype specifically in environments (macro or micro regions) that maximize the attributes of agronomic interest and then compile their trends in high productivity of quality grains. Due to the great difficulties of correctly estimating parameters, statistical alternatives obtained through fixed, mixed linear models and Bayesian probabilistic models are used so that these 
estimated parameters (mean and deviation or variance) can be used in modern multivariate methods of adaptability and stability which obtain the required results in detail.

The analysis of AMMI (Additive Main Effects and Multiplicative Interaction Analysis) is based on the joint action of univariate and multivariate analyzes and their responses are expressed by the decomposition of these parameters in just one model, combining the additive effects components of the genotypes, environments and the multiplicative effects of (GxE) interaction (Zobel et al., 1988).

This technique makes it possible to identify genotypes with high productivity and those that are widely adapted, it allows bringing together the most similar genotypes and environments, which will enable an agronomic zoning, as well as allowing the indication of promising regions for the growing of soybeans (Gauch and Zobel, 1996). Among the advantages of this method, we highlight the possibility of carrying out a detailed analysis of the genotype $\mathrm{x}$ environment interaction, ensuring efficient selection of genotypes, capitalizing on the positive interactions with the environments, providing accurate estimates of the genotypic responses, enabling an easy graphic interpretation of the results in biplot charts, where it simultaneously represents genotypes and environments (Zobel et al., 1988).

The GGE (Genotype and Genotypes by Environment Interaction) is a multivariate tool based on the definition of a plant or genotype ideotype developed for a given environment, which in turn reveals high performance and broad phenotypic stability, these definitions are established through consignment mega environments. This analysis considers the main effect of the genotype combined with the effects of the genotype $\mathrm{x}$ environment interaction. The analyzes are expressed graphically in a biplot form, allowing visualization ( $G G E$ biplot), that is, the average of the genotype $\mathrm{x}$ phenotypic stability (Yan et al., 2007; Yan, 2011).

The graphic representation via biplot was developed by Gabriel in 1971, with the intention of representing the results obtained in a two- dimensional plane, and interpreting them through analysis of the main components, where the magnitude of the element can be visualized by vectors in a plane of known dimensions (Yan and Kang, 2003). Researches carried out by Silva and Benin (2012) using the GGE model made it possible to explore the genotype $\mathrm{x}$ environment interaction more effectively, which reveals a greater accuracy in the identification of megaenvironments, in the selection of stable genotypes, and adapted to specific environments. Merit of the GGE biplot methodology is attributed when a large number of genotypes and several environments are used, allowing a better understanding of the effects of genotype $\mathrm{x}$ environment interaction. This work aims to estimate and predict the strategic positioning of wheat genotypes in the triticultural environments of Rio Grande do Sul, using fixed linear, mixed linear, and bayesian models.

\section{Material and methods}

The experiments were conducted in the 2013, 2014, 2015 and 2016 crop seasons in nine growing environments in the state of Rio Grande do Sul, using 24 wheat genotypes (Table 1 and Figure 1).

This research was developed in partnership with the Fundação Pró Semente from Passo Fundo. The experimental design used was randomized blocks organized in a factorial scheme, with four crop seasons (2013, 2014, 2015, and 2016), three repetitions $x$ nine growing environments (Cachoeira do Sul - RS - Season I (1st half of June) and Season II (2nd half of June), Cruz Alta - RS - Season I (1st half) and Season II (2nd half), Passo Fundo - RS, Santo Augusto - RS, São Gabriel - RS, São Luiz Gonzaga - RS and Vacaria - RS) x 24 wheat genotypes Ametista $\left(\mathrm{G}_{1}\right)$, BRS $327\left(\mathrm{G}_{2}\right)$, BRS $331\left(\mathrm{G}_{3}\right)$, BRS Marcante $\left(\mathrm{G}_{4}\right)$, BRS Parrudo $\left(\mathrm{G}_{5}\right)$, BRS Reponte $\left(\mathrm{G}_{6}\right)$, CD $123\left(\mathrm{G}_{7}\right)$, CD $1440\left(\mathrm{G}_{8}\right)$, CD $1550\left(\mathrm{G}_{9}\right)$, Celebra $\left(\mathrm{G}_{10}\right)$, Esporão $\left(\mathrm{G}_{11}\right)$, Estrela Átria $\left(\mathrm{G}_{12}\right)$, FPS Certero $\left(\mathrm{G}_{13}\right)$, Jadeíte 11 $\left(\mathrm{G}_{14}\right)$, LG Oro $\left(\mathrm{G}_{15}\right)$, LG Prisma $\left(\mathrm{G}_{16}\right)$, LG cromo $\left(\mathrm{G}_{17}\right)$, LG Supra $\left(\mathrm{G}_{18}\right)$, Marfim $\left(\mathrm{G}_{19}\right)$, Mirante $\left(\mathrm{G}_{20}\right)$, ORS $1401\left(\mathrm{G}_{21}\right)$, ORS $1402\left(\mathrm{G}_{22}\right)$, ORS $1403\left(\mathrm{G}_{23}\right)$, ORS $1405\left(\mathrm{G}_{24}\right)$, arranged in three repetitions. 
Table 1. Summary of analysis of variance (GLM), Components of variance and genetic parameters (REML and BAYES), and estimates of the sums and mean squares for the AMMI method.

\begin{tabular}{|c|c|c|c|c|c|c|c|c|}
\hline \multicolumn{3}{|l|}{ Variation factors } & DF & LS & \multicolumn{2}{|c|}{ Variation factors } & DF & LS \\
\hline \multicolumn{3}{|c|}{ Crop seasons (S) } & 3 & $476732603^{*}$ & \multicolumn{2}{|l|}{ S $\times E \times G$} & 552 & $746945^{*}$ \\
\hline \multicolumn{3}{|c|}{ Growing environments (E) } & 8 & $96936038^{*}$ & \multicolumn{2}{|c|}{ Blocks (S x E) } & 72 & $630305^{*}$ \\
\hline \multicolumn{3}{|l|}{$S \times E$} & $\begin{array}{l}24 \\
23\end{array}$ & \begin{tabular}{|c|}
$37214695^{*}$ \\
$8834750^{*}$
\end{tabular} & \multicolumn{2}{|c|}{ Residue } & 1656 & 204293 \\
\hline Genotypes (G) & \multicolumn{2}{|c|}{$S \times G$} & 69 & $\begin{array}{l}8834 / 50^{*} \\
949435^{*}\end{array}$ & \multicolumn{2}{|c|}{ Coefficient of variation } & & $11.57 \%$ \\
\hline Ex G & & & 184 & $815799^{*}$ & \multicolumn{2}{|c|}{ Determination coefficient } & & 0.92 \\
\hline \multirow{2}{*}{$\begin{array}{l}\text { Variation } \\
\text { factors }\end{array}$} & \multirow[t]{2}{*}{ DF } & \multicolumn{3}{|c|}{$\begin{array}{l}\text { AMMI - Generalized } \\
\text { linear models - GLM }\end{array}$} & \multicolumn{2}{|c|}{$\begin{array}{l}\text { AMMI - Mixed linear } \\
\text { models - MIXED }\end{array}$} & \multicolumn{2}{|c|}{$\begin{array}{l}\text { AMMI - Bayesian } \\
\text { inference - BAYES }\end{array}$} \\
\hline & & & S & LS & ss & LS & SS & LS \\
\hline Genotypes (G) & 23 & 1693 & 338.0 & $736232.09^{*}$ & 3.984394 & $1.732345^{*}$ & 3.492652 & $1.518544^{*}$ \\
\hline $\begin{array}{l}\text { Growing } \\
\text { environments } \\
\text { (E) }\end{array}$ & 8 & 6462 & 004.8 & $8078000.59^{*}$ & 6.567767 & $8.209708^{*}$ & 6.567765 & $8.209706^{*}$ \\
\hline $\mathbf{G} \times \mathbf{E}$ & 184 & 1250 & 874.5 & $67983.01^{*}$ & 4.020933 & $2.185290^{*}$ & 5.319511 & $2.891039^{*}$ \\
\hline EPCA I & 30 & 354 & 885.0 & $118102.83^{*}$ & 1.177985 & $3.926615^{*}$ & 4.974424 & $1.658141^{*}$ \\
\hline Residue & 330 & 1285 & 025.6 & 38939.47 & 4.130595 & 1.251695 & 5.464589 & 1.655936 \\
\hline
\end{tabular}

Components of variance and genetic parameters

\begin{tabular}{|c|c|c|c|}
\hline Deviance (LRT) & -+910.87 & $C^{2} G S A$ & 0.38 \\
\hline VG & 72283.00 & rGA & 0.91 \\
\hline VGS & 7593.86 & rGS & 0.90 \\
\hline VGA & 6515.45 & rGAXS & 0.92 \\
\hline $\begin{array}{c}\text { VGSA } \\
\text { VR }\end{array}$ & $\begin{array}{l}180203.44 \\
204275.87\end{array}$ & rSxA & 0.91 \\
\hline VF & 470871.64 & rGA_MS & 0.94 \\
\hline $\mathbf{H}^{2}$ & 0.15 & rGS_MA & 0.92 \\
\hline C' $^{2}$ SS & 0.01 & rGAS & 0.27 \\
\hline$C^{2} G A$ & 0.01 & General mean & 3903.62 \\
\hline
\end{tabular}

Growing environment

\begin{tabular}{cccc}
\cline { 2 - 4 } environment & Mixed $\left.\mathbf{( H}^{\mathbf{2}}\right)$ & Bayes $\left.\mathbf{( H}^{\mathbf{2}}\right)$ & Relative contribution (\%) \\
\hline I & 0.050854 & 0.050873 & 10.02 \\
\hline II & 0.081994 & 0.082025 & 16.16 \\
\hline III & 0.034075 & 0.034088 & 6.71 \\
\hline IV & 0.047326 & 0.047344 & 9.33 \\
\hline V & 0.025565 & 0.025575 & 5.04 \\
\hline VI & 0.028531 & 0.028542 & 5.62 \\
\hline VII & 0.082108 & 0.08214 & 16.18 \\
\hline VIII & 0.061838 & 0.061862 & 12.19 \\
\hline IX & 0.095156 & 0.095193 & 18.75 \\
\hline
\end{tabular}

DF: Degree of Freedom; LS: Latin Square; LRT: Deviance; GLM: Generalized Linear Model; MIXED: Mixed Linear Model; BAYES: Bayesian Inference; H2: Broad sense heritability, Mixed model: H2 Bayes: Bayesian model heritability. 


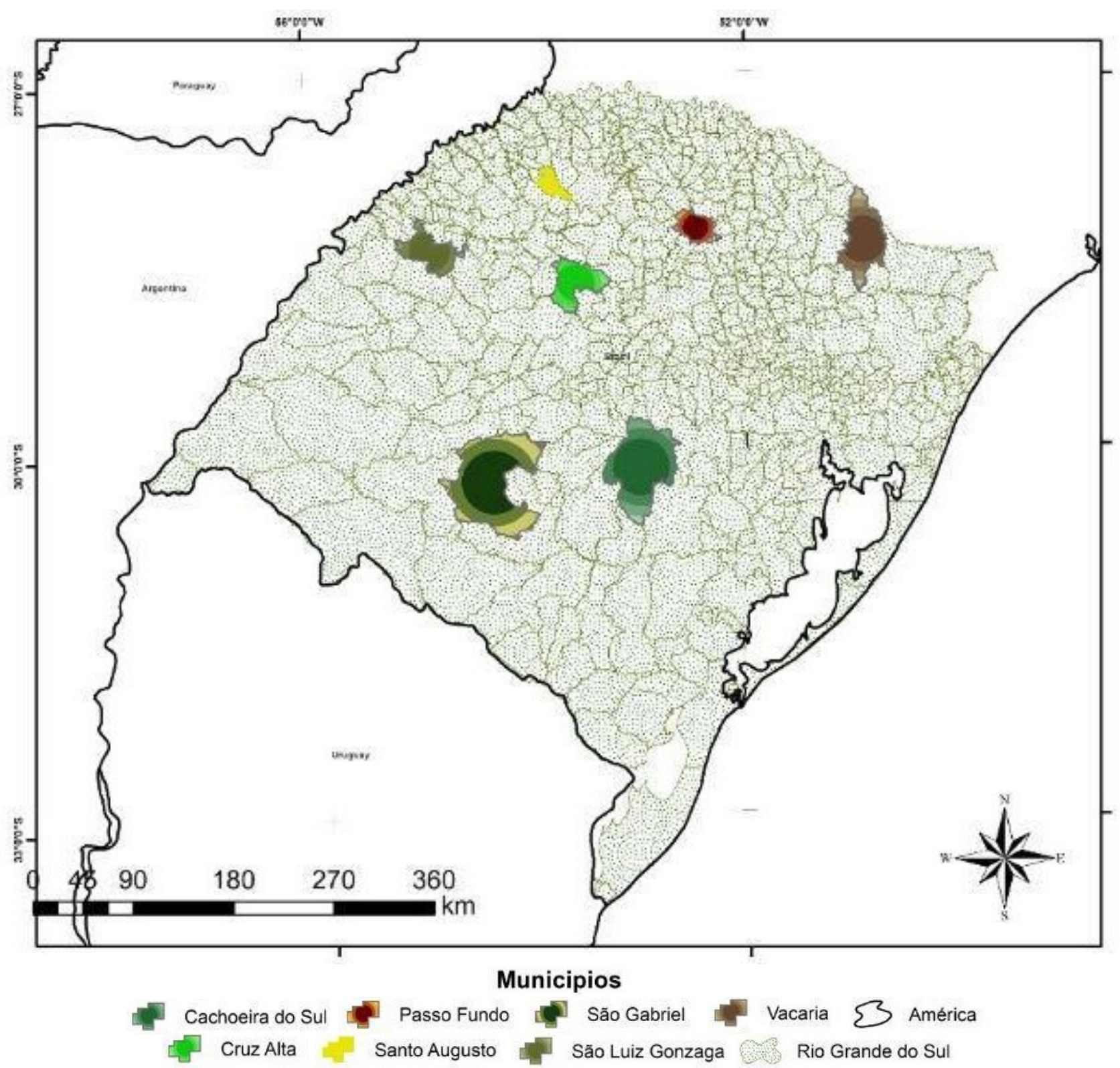

Figure 1 - Definition of growing environments: Environment I and II (season I and season II) Cachoeira do Sul-RS, environment III and IV (season I and season II) Cruz Alta-RS, environment (V) Passo Fundo-RS, environment (VI) Santo Augusto-RS, environment (VII) São Gabriel-RS, environment (VIII) São Luiz Gonzaga-RS, environment (IX) Vacaria-RS.

The experimental units consisted of five rows of sowing spaced 0.20 meters and five meters long. The sowing in the growing environments for the four crop seasons occurred in the first half of June of each harvest.

The population density used was 340 viable seeds per square meter. Nutritional management consisted of $300 \mathrm{~kg} \mathrm{ha}^{-1}$ of NPK in formulation 08-25-20 in the sowing base, $70 \mathrm{~kg} \mathrm{ha}{ }^{-1}$ of nitrogen was used for topdressing in the form of urea $(46 \% \mathrm{~N})$ in a single application in the stage of full tillering, the management of weeds, pest insects and diseases were standardized for all environments and genotypes, following the Technical Recommendations of Wheat (RCBPTT, 2012). The yield was obtained by harvesting the useful area of each experimental unit $(5.0 \mathrm{~m} 2)$, with the grain mass being adjusted to $13 \%$ moisture, later estimated in $\mathrm{kg} \mathrm{ha}^{-1}$.

The data obtained were subjected to analysis of variance at $5 \%$ probability where the assumptions, model additivity, normality of residues, and homogeneity of variances were verified (Ramalho et al., 2000). Subsequently, the interaction between crop seasons $\mathrm{x}$ growing environments $\mathrm{x}$ wheat genotypes was identified 
at $5 \%$ probability. In the presence of significant $\mathrm{G} \times \mathrm{E}$ interaction, the AMMI method was used, which combines the variances of the additive effects of genotypes and growing environments with the multiplicative effects of the interaction (GxE), which later the obtained scores were represented in biplot graphs through multivariate methodology of the main components (Zobel et al., 1988). The AMMI model was performed based on the phenotypic inferences of seed yield.

$$
Y_{i j}=\mu+g_{i}+e_{j}+\Sigma_{k=1}^{n} \lambda_{k} \gamma_{i k} \alpha_{j k}+\rho_{i j}+\varepsilon_{i j}
$$

Where: Yij: represents the average response of the experimental units of the $\mathrm{i}^{\text {th }}$ genotype $(i)$ in the $\mathrm{j}^{\text {th }}$ growing environment $(j) ; \mu$ : corresponds to the general average of genotypes in growing environments; $g i$ : presents itself as the main effect attributed to genotype $i ; a j$ : represents the main effect of the growing environment $j ; \lambda k, y i k$ and $\alpha j k$ : correspond to the terms referring to the decomposition of the $\mathrm{G} \times \mathrm{E}$ matrix that captures the pattern associated with the interaction of genotype $i$ with the growing environment $j$, ponders the additive deviations of the character of interest $(Y i j)$ in relation to the main effects of $g i$ and $a j$; $\rho i j$ : represents the noise that will be eliminated from the analysis relative to the $\mathrm{G} \times \mathrm{E}$ interaction; $\varepsilon i j$ : corresponds to the experimental error (Duarte and Vencovsky, 1999).

The GGE method combines the effects attributed to the tested genotypes and the $\mathrm{G} \times \mathrm{E}$ interaction (Yan et al., 2000). It makes possible the identification of the genotype with high performance, which is efficient in a determined growing environment, in the same way, it allows the formation of macroenvironments (Woyann et al., 2016). The GGE model was performed based on the phenotypic inferences of seed production.

\section{(Eq. 2)}

$$
Y_{i j}-\mu-\beta_{j}=\lambda_{1} \xi_{1 j} n_{1 j}+\lambda_{2} \xi_{2 j} n_{2 j}+\varepsilon_{i j}
$$

Where: Yij: represents the expected magnitude for genotype $i$ grown in environment $j ; \mu$ : corresponds to the general average of $Y i j$ observations; $\beta j$ : it is evident as the main effect attributed to the growing environment $j ; \lambda 1$ and $\lambda 2$ : correspond to the main (PC I) and secondary (PC II) scores that are determinant for graphic expression through the main biplot components; $\xi 1 j$ and $\xi 2 j$ : show themselves as the eigenvectors that represent genotype $i$ in the abscissa axes of PC I and PC II; $\varepsilon i j$ : expresses the unadjusted residual from the effects of the statistical model.

The method based on the Restricted Maximum Likelihood (REML) was carried out in order to estimate the components of variance and genetic parameters, where the significance was obtained through Deviance analysis at 5\% probability by the chi-square test (Resende, 2007). For this, the statistical model was used:

$$
Y=X r+Z g+W i+e
$$

Where: $y$ : is the data vector, $r$ : are the effects of repetitions (fixed), $g$ : are the genotypic effects (random), $i$ : are the effects of the interaction between crop seasons $\mathrm{x}$ growing environments $\mathrm{x}$ genotypes (random), $e$ : are the residues (random), $\mathrm{X}, \mathrm{Z}$ and $\mathrm{W}$ are incidence matrices that relate, respectively, the effects of $r, g$ and $i$ to the vector $\mathrm{y}$. Thus, it was estimated the genotypic variance $\left(\sigma^{2} G\right)$, variance of the genotype $\mathrm{x}$ environment interaction $\left(\sigma^{2} I N T\right)$, phenotypic variance $\left(\sigma^{2} F\right)$, residual variance $(V e)$, broad sense heritability of the genotype mean $\left(\hat{h}^{2} m g\right)$, accuracy for the genotype selection (Acgen), coefficient of determining the effects of genotype $\mathrm{x}$ environment interaction $\left(C^{2} I N T\right)$, genotypic correlation between the performance of environments $(\mathrm{rgloc})$, coefficient of genotypic variation $(\mathrm{CVg})$, coefficient of residual variation $(\mathrm{CVe})$ and the general mean of the characters. REML / BLUP estimates and predictions were used to the multivariate GGE method, to obtain inferences based on genetic effects and it was called the predicted genetic GGE approach.

Bayesian inference was carried out using the Markov chain Monte Carlo method (MCMC) using Gibbs sampler, first a priori distributions of the genetic value of each genotype grown in each crop season and growing environment were constructed, these distributions were obtained through the mean predicted by BLUP $\left(\mu^{0}\right)$ and 
the genetic standard deviation $\left(\sigma^{0}\right)$ obtained and subsequently squared $\left(\sigma^{20}\right.$ to obtain the genetic variance. The posterior distribution was obtained through 1000000 iterations, where the new probabilistic average genetic parameters $\left(\mu^{1)}\right.$ and probabilistic genetic variance ${ }^{(} \sigma^{21)}$ were obtained.

The AMMI and GGE adaptability and stability models were applied to the three statistical scenarios, defining that scenario I represents the estimates obtained by the fixed linear model (GLM), scenario II expresses the estimates and predictions obtained by the mixed linear model (MIXED) and scenario III shows the probabilistic predictions obtained by the Bayesian inference (BAYESIAN). Statistical Analysis System ${ }^{\circledR}$ (STATISTICAL ANALYSIS SYSTEM, 2003), GENES® (Cruz et al., 2013), R Core Team, 2015 ${ }^{\circledR}$ (R Core Team, 2015) and Selegen ${ }^{\circledR}$ (Resende, 2007) were used to make the statistical analysis.

\section{Results and discussion}

The fixed linear model (GLM) showed for the analysis of variance that (Table 1) the explanatory variation sources for wheat grain yield in Rio Grande do Sul attributed the crop seasons (years) as the major contribution to the total variation expressed, in this context, there was significant interaction between crop season $x$ growing environment $x$ wheat genotypes at $5 \%$ probability for the response character. The coefficient of variation was low with only $11.57 \%$, which reveals high reliability in the estimates, as well as the coefficient of determination (R2) was high for both the statistical model represents $92 \%$ of the total variability of the phenomenon under study.

The phenotypic trends were subjected to the model that bases its estimation parameters on the restricted maximum likelihood (REML), for this purpose, the premises of the mixed linear models (MIXED) are used where the effects of the interaction between crop seasons $\mathrm{x}$ growing environments $\mathrm{x}$ wheat genotypes were considered random. The maximum restricted likelihood ratio (RLT - + 919.81) obtained by Deviance showed significance at 5\% probability by the chi-square test $\left(\mathrm{x}^{2}\right)$, so the model used is consistent and reliable. Based on the estimates of the variance components, the grain yield of wheat in the state of Rio Grande do Sul is determined by a fraction of $15 \%$ due to the genetic effects intrinsic to the characteristics of the genotype used, and the remaining $85 \%$ are due to the growing environment, management and cultural practices employed. It is essential to understand the parameter of heritability to refine the estimates, since it comes from the genetic variance weighted by the phenotypic, the assertiveness in the strategic positioning of the cultivar may reflect in the future on high yields that can be ensured by the great genetic contribution. The genetic variance is minimally constant between the studied crop seasons, however, it shows greater effects between the growing environments in the same crop season.

The genotypic correlation of the expressions of the genetic characteristics of the genotype submitted to growing in different crop seasons and environments showed low coefficients, which indicates that the triple interaction (rSEG) has complex origins and characteristics, with major changes in trends imposed by the peculiarities of each environment. In contrast, the genetic correlations of performance are high with a simple nature when the interactions of genotypes $\mathrm{x}$ growing environment ( $\mathrm{rGE}$ ) or genotypes $\mathrm{x}$ crop seasons (rGS) are listed.

For a better understanding of which growing environments revealed the greatest genetic contributions to wheat grain yield regardless of the crop season, the exclusive heritability parameter was estimated for each environmental condition, as well as, mixed linear models were used with the probabilistic estimates and predictions of the Bayesian models. Basing the estimates both methods followed the trend that the environment Vacaria - RS (IX: E9), São Gabriel - RS (VII: E7) and Cachoeira do Sul - RS Season II, (II: E2) expressed the greatest individual heritabilities, under these conditions the grain yield is maximized by the genetic potential of the cultivar, whereas the environment Vacaria - RS (IX: E9) contributed $18.75 \%$ to the total genetic effects of the experiment, this environment is considered to be of high potential to maximize the productive characteristics of wheat. 


\section{Additive main effects and multiplicative interaction - AMMI based on fixed linear models (GLM)}

This method based on the fixed linear model (Table 2 and Figure 2) revealed that the grain yield character was ranked through the genotypes with the highest averages, such as ORS 1402 (G22), LG Oro (G15), and the Jadeíte genotype 11 (G14). In this context, the genotypes that presented means higher than the general average of the experiment were ORS 1403 (G23), Parrudo (G5),
LG Supra (G18), ORS 1405 (G24), BRS 327 (G2), Jadeíte 11 (G14), LG Oro (G15), Marfim (G19), LG cromo (G17), CD 1440 (G8) and ORS 1402 (G22).

When referring to genotypes above the general average and specifically adapted to favorable environments (environments VIII: E8 and VII: E7), the genotypes ORS 1403 (G23), Parrudo (G5), LG Supra (G18), ORS 1405 (G24), BRS 327 (G2), Jadeíte 11 (G14) and LG Oro (G15) are highlighted.

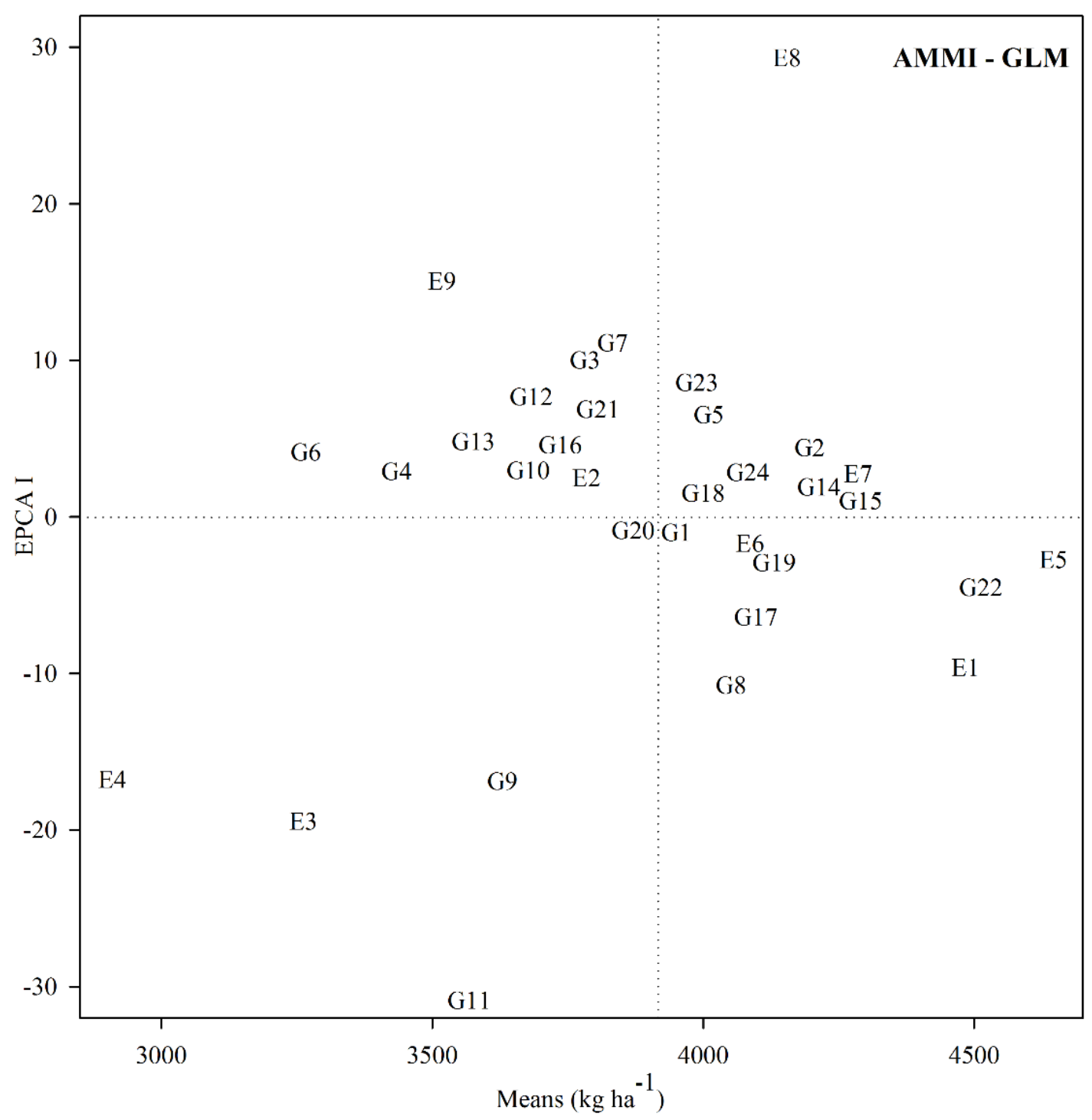

Figure 2. Additive Main effects and Multiplicative Interaction - AMMI based on fixed linear models (GLM): Ametista (G1), BRS 327 (G2), BRS 331 (G3), BRS MARCANTE (G4), BRS PARRUDO (G5), BRS REPONTE (G6), CD 123 (G7), CD 1440 (G8), CD 1550 (G9), CELEBRA (G10), ESPORÃO (G11), ESTRELA ÁTRIA (G12), FPS CERTERO (G13), JADEÍTE 11 (G14), LG ORO (G15), LG PRISMA (G16), LG CROMO (G17), LG SUPRA (G18), MARFIM (G19), MIRANTE (G20), ORS 1401 (G21), ORS 1402 (G22), ORS 1403 (G23), ORS 1405 (G24), evaluated in nine growing environments: Environment I and II (season I and season II) Cachoeira do Sul-RS, season I (1st half of June) and season II (2nd half of June), environment III and IV (season I and season II) Cruz Alta-RS, season I (1st half of June) and season II (2nd half of June), environment (V) Passo Fundo-RS, environment (VI) Santo Augusto-RS, environment (VII) São Gabriel-RS, environment (VIII) São Luiz Gonzaga-RS, environment (IX) Vacaria-RS. 
Table 2. Means and scores for the effects of the AMMI method obtained for the fixed linear models, mixed linear models, and Bayesian models.

\begin{tabular}{lccccccc}
\hline \multirow{2}{*}{ Genotypes } & \multicolumn{2}{c}{$\begin{array}{c}\text { Generalized linear } \\
\text { models - GLM }\end{array}$} & $\begin{array}{c}\text { Mixed linear } \\
\text { models- MIXED }\end{array}$ & \multicolumn{3}{c}{$\begin{array}{c}\text { Bayesian inference } \\
\text { BAYES }\end{array}$} \\
\cline { 2 - 8 } & Mean & EPCA I & Mean & EPCA I & Mean & EPCA I & Amplitude \\
\hline G1Ametista & 3915 & -1.43 & 4093 & 1.18 & 4072 & 6.60 & 711 \\
\hline G2 BRS 327 & 4196 & 4.42 & 4268 & -0.91 & 4232 & 12.01 & 2638 \\
\hline G3 BRS 331 & 3781 & 5.00 & 4043 & 2.81 & 4032 & 3.20 & 1281 \\
\hline G4 BRS MARCANTE & 3434 & 2.89 & 3928 & 0.88 & 3932 & -1.53 & 3761 \\
\hline G5 BRS PARRUDO & 4010 & 6.51 & 4140 & -1.44 & 4121 & 5.33 & 936 \\
\hline G6 BRS REPONTE & 3266 & 4.12 & 3903 & 0.86 & 3914 & -3.46 & 4907 \\
\hline G7 CD 123 & 3833 & 11.10 & 4070 & 0.39 & 4063 & 1.93 & 681 \\
\hline G8 CD 1440 & 4051 & -10.76 & 4164 & -0.05 & 4152 & 5.00 & 1239 \\
\hline G9 CD 1550 & 3629 & -16.89 & 3966 & 1.67 & 3974 & -2.86 & 2117 \\
\hline G10 CELEBRA & 3677 & 2.96 & 3985 & 1.27 & 3991 & -2.80 & 1796 \\
\hline G11 ESPORÃO & 3568 & -30.90 & 3950 & -0.12 & 3964 & -4.51 & 2488 \\
\hline G12 ESTRELA ÁTRIA & 3682 & 7.66 & 3987 & 0.20 & 3999 & -3.82 & 1702 \\
\hline G13 FPS CERTERO & 3776 & 4.80 & 4029 & -1.92 & 4038 & -2.72 & 1000 \\
\hline G14 JADEITE 11 & 4233 & 1.10 & 4298 & 2.04 & 4279 & 6.42 & 2524 \\
\hline G15 LG ORO & 4290 & 1.00 & 4345 & -5.06 & 4322 & 7.51 & 3031 \\
\hline G16 LG PRISMA & 3736 & 4.59 & 4012 & 0.68 & 4027 & -4.85 & 1380 \\
\hline G17 LG CROMO & 4097 & -6.39 & 4201 & 0.99 & 4199 & 1.50 & 1582 \\
\hline G18 LG SUPRA & 4026 & 2.50 & 4143 & 2.38 & 4147 & -1.37 & 1063 \\
\hline G19 MARFIM & 4131 & -2.92 & 4233 & 0.35 & 4230 & 1.24 & 1868 \\
\hline G20 MIRANTE & 3958 & -0.89 & 4111 & 1.93 & 4124 & -3.96 & 607 \\
\hline G21 ORS 1401 & 3806 & 6.84 & 4054 & 0.54 & 4070 & -7.15 & 975 \\
\hline G22 ORS 1402 & 4512 & -4.51 & 4447 & -5.86 & 4427 & 5.57 & 4806 \\
\hline G23 ORS 1403 & 3988 & 6.57 & 4127 & -3.26 & 4151 & -7.47 & 967 \\
\hline G24 ORS 1405 & 4082 & 2.61 & 4189 & 0.41 & 4218 & -9.80 & 1897 \\
\hline
\end{tabular}

Growing environments

\begin{tabular}{cccccccc}
\hline \multirow{2}{*}{ Genotypes } & \multicolumn{2}{c}{$\begin{array}{c}\text { Generalized linear } \\
\text { models - GLM }\end{array}$} & \multicolumn{2}{c}{$\begin{array}{c}\text { Mixed linear } \\
\text { models- MIXED }\end{array}$} & \multicolumn{3}{c}{$\begin{array}{c}\text { Bayesian inference } \\
\text { BAYES }\end{array}$} \\
\cline { 2 - 8 } & Mean & EPCA I & Mean & EPCA I & Mean & EPCA I & Amplitude \\
\hline I & 4484 & -9.62 & 4707 & -6.91 & 4707 & 4.47 & 2009 \\
II & 3784 & 4.48 & 3992 & 0.86 & 3992 & 3.77 & 1907 \\
III & 3262 & -19.44 & 3466 & -0.39 & 3466 & 3.30 & 1864 \\
\hline IV & 2909 & -16.78 & 3108 & -0.17 & 3108 & 2.52 & 1837 \\
V & 4646 & -2.74 & 4853 & 4.39 & 4853 & 2.60 & 1948 \\
VI & 4086 & -2.99 & 4301 & 0.23 & 4301 & 2.73 & 1981 \\
VII & 4285 & 2.73 & 4494 & 5.53 & 4494 & 3.01 & 1906 \\
\hline VIII & 4154 & 29.31 & 4361 & -3.09 & 4361 & 2.53 & 1870 \\
\hline IX & 3518 & 15.05 & 3724 & -0.44 & 3724 & -24.97 & 1912 \\
\hline
\end{tabular}

Genotypes: Ametista (G1), BRS 327 (G2), BRS 331 (G3), BRS MARCANTE (G4), BRS PARRUDO (G5), BRS REPONTE (G6), CD 123 (G7), CD 1440 (G8), CD 1550 (G9), CELEBRA (G10), ESPORÃO (G11), ESTRELA ÁTRIA (G12), FPS CERTERO (G13), JADEÍTE 11 (G14), LG ORO (G15), LG PRISMA (G16), LG CROMO (G17), LG SUPRA (G18), MARFIM (G19), MIRANTE (G20), ORS 1401 (G21), ORS 1402 (G22), ORS 1403 (G23), ORS 1405 (G24), evaluated in nine growing environments: Environment I and II (season I and season II) Cachoeira do Sul-RS, season I (1st half of June) and season II (2nd half of June), environment III and IV (season I and season II) Cruz Alta-RS, season I (1st half of June) and season II (2nd half of June), environment (V) Passo Fundo-RS, environment (VI) Santo AugustoRS, environment (VII) São Gabriel-RS, environment (VIII) São Luiz Gonzaga-RS, environment (IX) Vacaria-RS.

The genotypes close to the horizontal midline reveal those scores responsible for phenotypic stability or predictability of the response, in this context, the genotypes LG Supra
(G18), Jadeíte (G14), LG Oro (G15), Mirante (G20), Ametista (G1) are ranked. According to the model, Ametista (G1), LG Supra (G18), and LG Oro (G15) appear to be stable and superior to 
the general average of the experiment. For this method specifically through the fixed linear model, estimates were obtained as environments favorable to wheat growing, environments São Luiz Gonzaga - RS (VIII: E8) and Santo Augusto - RS (VII: E7) and unfavorable Cruz Alta - RS Season II (IV: E4) and Cruz Alta Season I (III: E3). The genotypes expressed as unfavorable were listed as those contained in the lower left quadrant of the biplot representation, which are: CD 1550 (G9) and Esporão (G11).

\section{Additive main effects and multi- plicative interaction - AMMI based on mixed linear models (MIXED)}

The AMMI adaptability and stability model based on mixed linear models, was obtained through the statistical principle of restricted maximum likelihood (REML), thus, it was possible to minimize the discrepancies of the experimental residues so that the parameter estimates were based only on the predicted genetic values. (Figure 3 ).

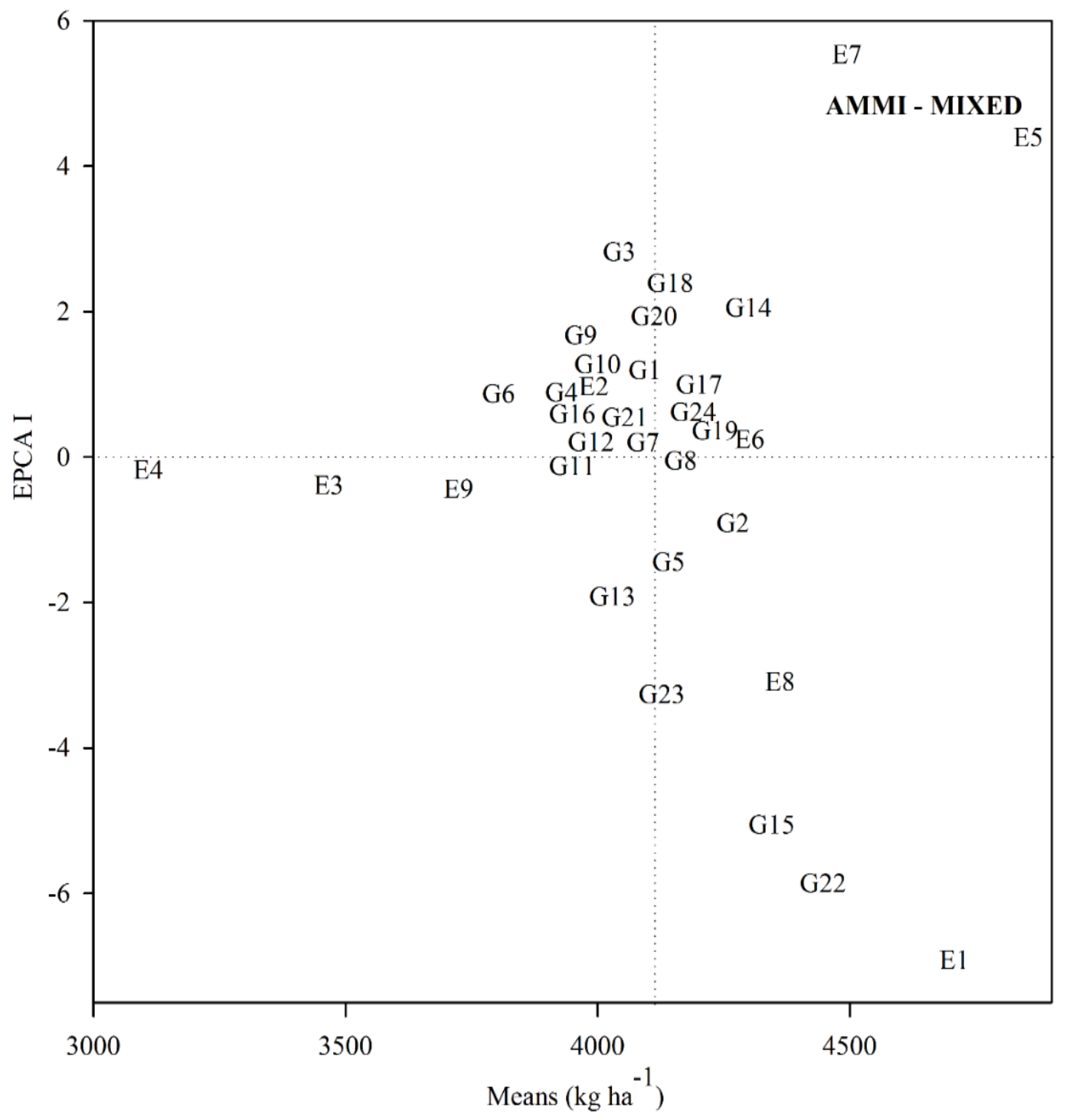

Figure 3. Additive Main effects and Multiplicative Interaction - AMMI based on mixed linear models: Ametista (G1), BRS 327 (G2), BRS 331 (G3), BRS MARCANTE (G4), BRS PARRUDO (G5), BRS REPONTE (G6), CD 123 (G7), CD 1440 (G8), CD 1550 (G9), CELEBRA (G10), ESPORÃO (G11), ESTRELA ÁTRIA (G12), FPS CERTERO (G13), JADEÍTE 11 (G14), LG ORO (G15), LG PRISMA (G16), LG CROMO (G17), LG SUPRA (G18), MARFIM (G19), MIRANTE (G20), ORS 1401 (G21), ORS 1402 (G22), ORS 1403 (G23), ORS 1405 (G24), evaluated in nine growing environments: Environment I and II (season I and season II) Cachoeira do Sul-RS, season I (1st half of June) and season II (2nd half of June), environment III and IV (season I and season II) Cruz Alta-RS, season I (1st half of June) and season II (2nd half of June), environment (V) Passo Fundo-RS, environment (VI) Santo Augusto-RS, environment (VII) São Gabriel-RS, environment (VIII) São Luiz Gonzaga-RS, environment (IX) Vacaria-RS. 
The genotypes with the highest average grain yield were ORS 1402 (G22), LG Oro (G15), and the genotype Jadeíte 11 (G14). In this context, the genotypes that presented means higher than the general average of the experiment were (G18), Mirante (G20), Jadeíte 11 (G14), LG cromo (G17), ORS 1405 (G24), Marfim (G19), CD 1440 (G8), BRS 327 (G2), Parrudo (G5), ORS 1403 (G23), LG Oro (G15), and ORS 1402 (G22). When referring to genotypes superior to the general average and specifically adapted to favorable environments, they are: São Gabriel RS (VII: E7), Passo Fundo - RS (V: E5), and São Gabriel - RS (VI: E6). The genotypes LG SUPRA (G18), Mirante (G20), Jadeíte 11 (G14), LG cromo (G17), ORS 1405 (G24), Marfim (G19), and CD 1440 (G8) are highlighted.

The genotypes close to the horizontal midline reveal those scores responsible for phenotypic stability or predictability of the response, in this context, the genotypes, CD 123 (G7), CD 1440 (G8), and Marfim (G19) are listed. According to the model, they show themselves as stable genotypes and superior to the general average of the experiment CD 1440 (G8) and Marfim (G19).

For this method specifically through the mixed linear model, estimates were obtained as favorable environments for wheat growing environments, Santo Augusto - RS (VI: E6), Passo Fundo - RS (V: E5), São Gabriel - RS (VII: E7), and unfavorable Cruz Alta - RS, season II (IV: E4), Cruz Alta - RS, season I (III: E3), and Vacaria - RS (IX: E9). The genotypes expressed as unfavorable were listed as those contained in the lower left quadrant of the biplot representation, which are: Esporão (G11) and FPS Certero (G13).

\section{Additive main effects and multiplicative interaction - AMMI based on Bayesian models (MCMC)}

The AMMI model based on Bayesian probabilistic predictions was obtained through the a priori distribution of each genotype grown in each environment, thus probabilistically simulating the a posteriori genetic tendency. The genotypes with the highest average grain yield were ORS 1402 (G22), LG Oro (G15), BRS 327 (G2). In this context, the genotypes that presented averages above the general average of the experiment were BRS 327 (G2), LG Oro (G15), Jadeíte (G14), BRS Parrudo (G5), CD 1440 (G8), ORS 1402 (G22), LG cromo (G17), Marfim (G19), LG Supra (G18), ORS 1403 (G23), ORS 1405 (G24). When referring to genotypes above the general average and specifically adapted to favorable environments, Santo Augusto - RS (VII: E6), São Luiz Gonzaga - RS (VIII: E8), São Gabriel - RS (VII: E7), Cachoeira do Sul, season I (I: E1), Passo Fundo RS (V: E5) the genotypes are evident, BRS 327 (G2), LG Oro (G15), Jadeíte (G14), BRS Parrudo (G5), CD 1440 (G8), ORS 1402 (G22), LG cromo (G17), Marfim (G19).

The genotypes close to the horizontal midline reveal those scores responsible for the phenotypic stability or predictability of the response, in this context, the Marfim genotype (G19) is listed, stable and superior to the general average of the experiment. Through the Bayesian model, estimates of favorable environments for wheat growing were obtained, environments, Santo Augusto - RS (VI: E6), São Luiz Gonzaga RS (VIII: E8), São Gabriel - RS (VII: E7), Cachoeira do Sul, season I (I: E1), Passo Fundo RS V: E5), and unfavorable Vacaria - RS (IX: E9). The genotypes considered as unfavorable were listed as those contained in the lower left quadrant of the biplot representation, which are: Esporão (G11) and FPS Certero (G13) (Figure 4).

\section{Genotype and genotypes by environments interaction (GGE) based on fixed linear models (GLM)}

The model is explaining the interaction at $73.54 \%$. By the GGR-GLM method, according to (Figure 5). There is no formation of agricultural macroenvironment. The genotypes in the position of the points of the polygon are the ones with the best performance, being these: CD 123 (G7), ORS 1402 (G22), Esporão (G11), and CD 1440 (G8). The environments with the best performance, that is, naturally higher average yield, were: Vacaria - RS (IX: E9), Cachoeira do Sul - RS, season II (II: E2), São Gabriel - RS 
(VII: E7), Cruz Alta-RS, season II (IV: E4), Cruz Alta - RS, season I (III: E3), and São Luiz Gonzaga - RS (VIII: E9).

The model also shows which genotypes are most specifically adapted for each environment. The BRS 327 (G2) genotype is specific to the Cachoeira do Sul environment, season II (II: E2), the LG Oro genotype (G15) is specific to the São Gabriel - RS environment (VII: E7), the ORS 1402 genotype (G22) is specific to the Santo Augusto - RS environment (VI: E6) (Figure 5).

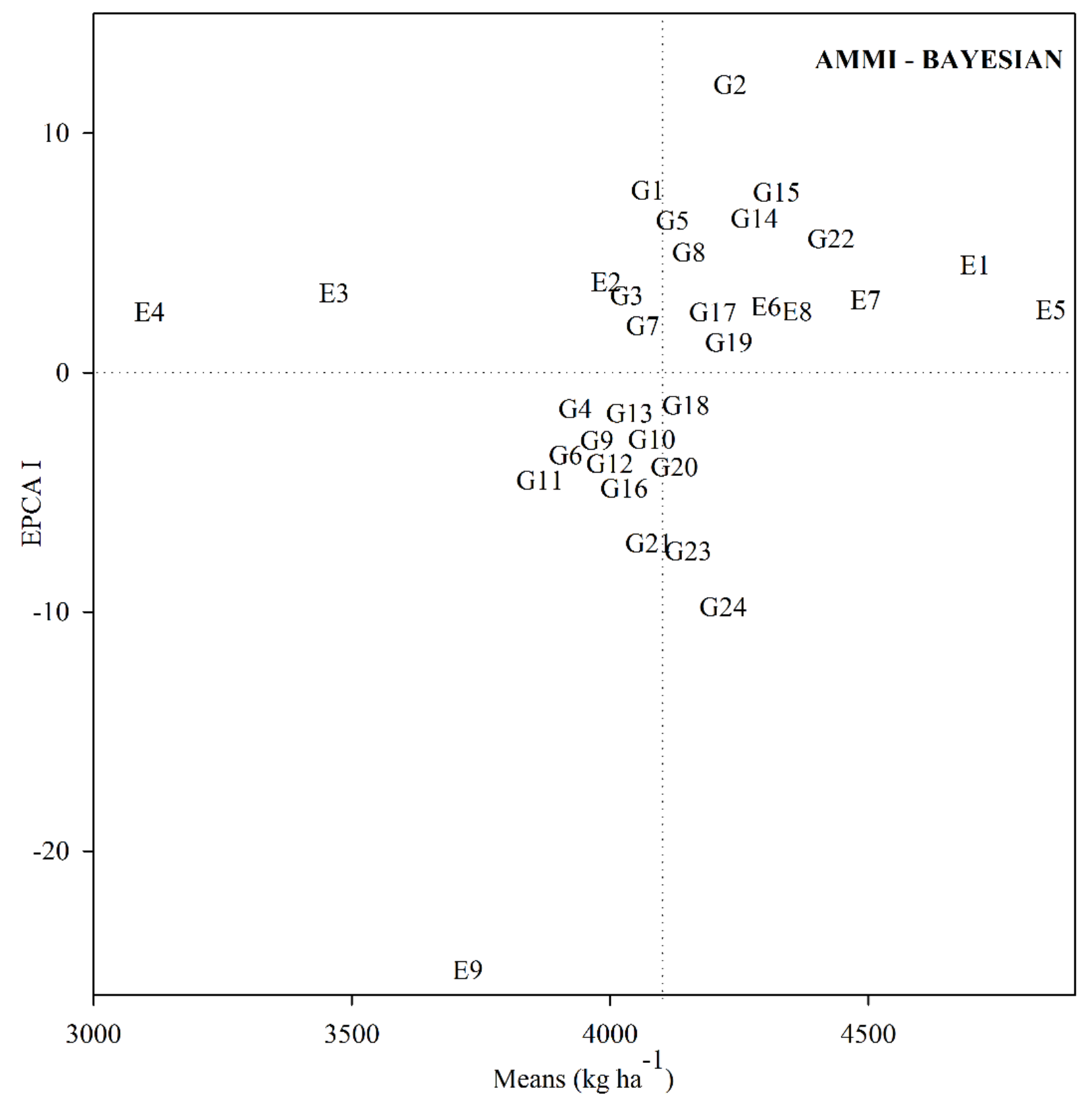

Figure 4. Additive Main effects and Multiplicative Interaction - AMMI based on Bayesian models (MCMC): Ametista (G1), BRS 327 (G2), BRS 331 (G3), BRS MARCANTE (G4), BRS PARRUDO (G5), BRS REPONTE (G6), CD 123 (G7), CD 1440 (G8), CD 1550 (G9), CELEBRA (G10), ESPORÃO (G11), ESTRELA ÁTRIA (G12), FPS CERTERO (G13), JADEÍTE 11 (G14), LG ORO (G15), LG PRISMA (G16), LG CROMO (G17), LG SUPRA (G18), MARFIM (G19), MIRANTE (G20), ORS 1401 (G21), ORS 1402 (G22), ORS 1403 (G23), ORS 1405 (G24), evaluated in nine growing environments: Environment I and II (season I and season II) Cachoeira do Sul-RS, season I (1st half of June) and season II (2nd half of June), environment III and IV (season I and season II) Cruz Alta-RS, season I (1st half of June) and season II (2nd half of June), environment (V) Passo Fundo-RS, environment (VI) Santo Augusto-RS, environment (VII) São Gabriel-RS, environment (VIII) São Luiz Gonzaga-RS, environment (IX) Vacaria-RS. 


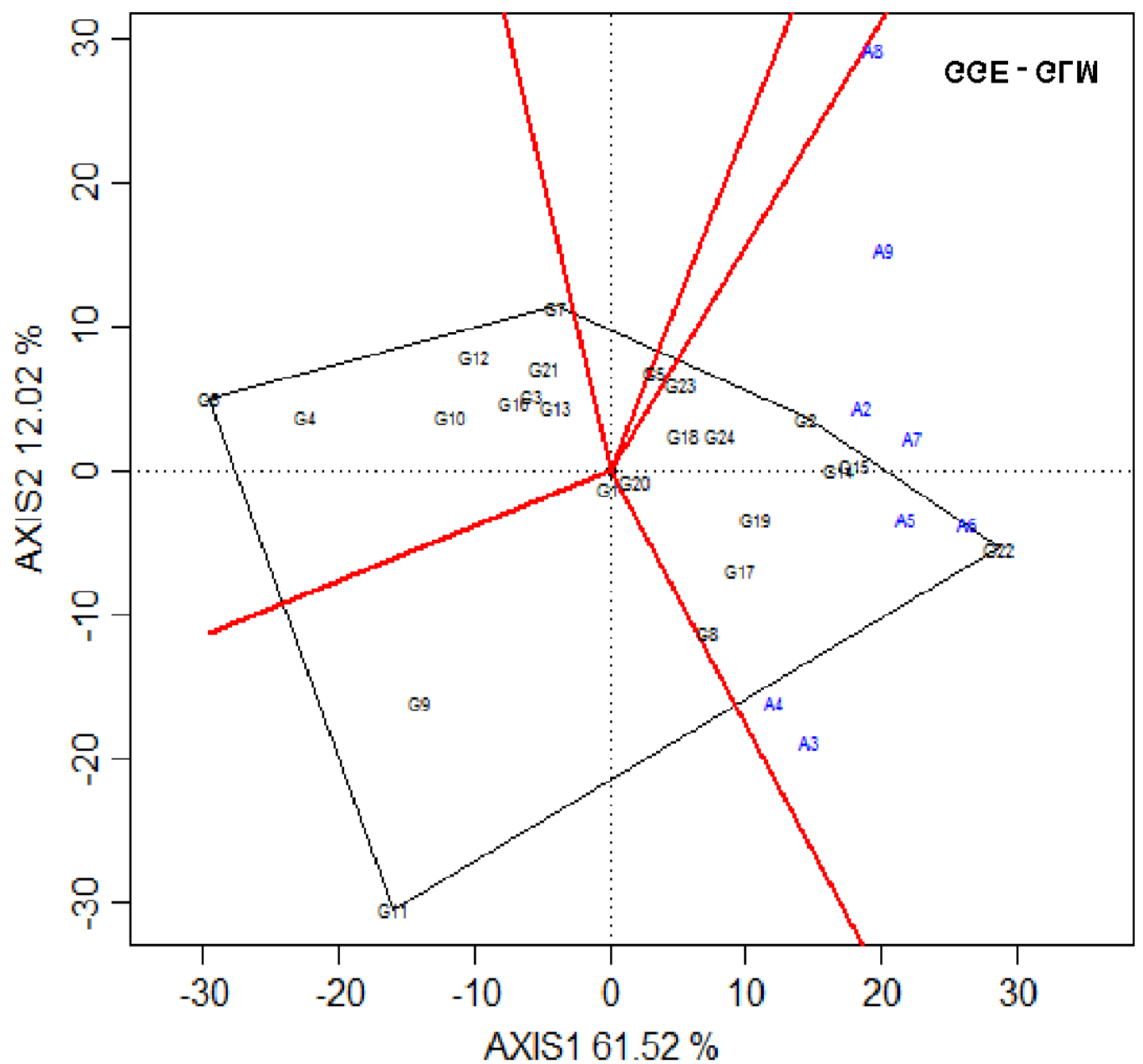

Figure 5. Genotype and Genotypes by Environments interaction (GGE) based on fixed linear models (GLM): Ametista (G1), BRS 327 (G2), BRS 331 (G3), BRS MARCANTE (G4), BRS PARRUDO (G5), BRS REPONTE (G6), CD 123 (G7), CD 1440 (G8), CD 1550 (G9), CELEBRA (G10), ESPORÃO (G11), ESTRELA ÁTRIA (G12), FPS CERTERO (G13), JADEÍTE 11 (G14), LG ORO (G15), LG PRISMA (G16), LG CROMO (G17), LG SUPRA (G18), MARFIM (G19), MIRANTE (G20), ORS 1401 (G21), ORS 1402 (G22), ORS 1403 (G23), ORS 1405 (G24), evaluated in nine growing environments: Environment I and II (season I and season II) Cachoeira do Sul-RS, season I (1st half of June) and season II (2nd half of June), environment III and IV (season I and season II) Cruz Alta-RS, season I (1st half of June) and season II (2nd half of June), environment (V) Passo Fundo-RS, environment (VI) Santo Augusto-RS, environment (VII) São Gabriel-RS, environment (VIII) São Luiz Gonzaga-RS, environment (IX) Vacaria-RS.

\section{Genotype and genotypes by environments interaction (GGE) based on mixed linear models (MIXED)}

The model is explaining $99.44 \%$ to the interaction, the GGE method that combines the effects attributed to the genotypes and the interaction $(\mathrm{GxE})$, in the mixed linear model, as shown in (Figure 6). It is possible to form a macroenvironment called macroenvironment I, composed of the environments: São Gabriel - RS (VII: E7) and São Luiz Gonzaga - RS (VIII: E8).
The high-performance genotypes are those positioned at the ends of the polygon, namely: ORS 1402 (G22), Jadeíte 11 (G14), BRS 331 (G3), BRS Parrudo (G5), BRS 327 (G2). The environments that performed better, that is, readily had higher productivity averages, were the environments: São Gabriel - RS (VII: E7) and São Luiz Gonzaga - RS (VIII: E8). The genotypes specifically adapted to the environment are specified according to their proximity, which are: genotype LG Oro (G15) is specific to the Vacaria environment (IX: E9), 
Jadeíte 11 (G14) genotype is specific to the São Gabriel - RS environment (VII: 7) (Figure 6).

\section{Genotype and genotypes by environments interaction (GGE) based on bayesian models (MCMC)}

The model is explaining $76.85 \%$ to the interaction, in the GGE method based on the Baysian model, (Figure 7). Demonstrating the formation of two macroenvironments. The first one, called macroenvironment I, is composed of the environments: Passo Fundo - RS (V: E5) and São Gabriel - RS (VII: E7). Macroenvironment II is composed of Cachoeira do Sul - RS, season II (II: E2), Passo Fundo - RS (V: E5), Cruz Alta RS, season II (III), Cachoeira do Sul - RS, season I (I: E1), and Cruz Alta - RS, secondseason (IV: E4). The genotypes distributed at the ends of the polygon are highlighted by the best performance (grain yield) in relation to the others, these being: Jadeíte 11 (G14), BRS 327 (G2), FPS Certero (G13), ORS 1403 (G23), ORS 1405 (G24), Mirante (G20) (Figure 7).

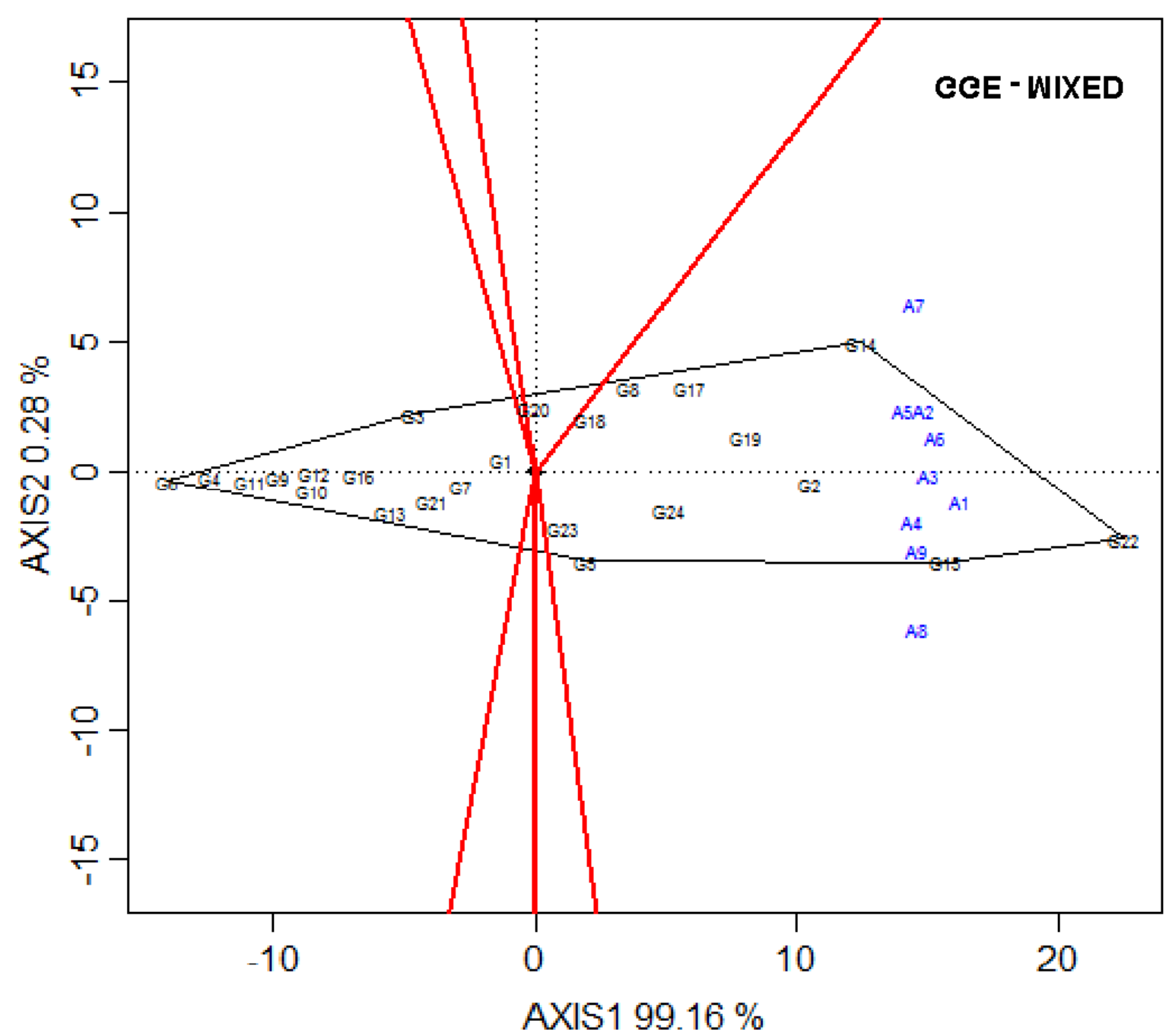

Figure 6. Genotype and Genotypes by Environments interaction (GGE) based on mixed linear models (MIXED): Ametista (G1), BRS 327 (G2), BRS 331 (G3), BRS MARCANTE (G4), BRS PARRUDO (G5), BRS REPONTE (G6), CD 123 (G7), CD 1440 (G8), CD 1550 (G9), CELEBRA (G10), ESPORÃO (G11), ESTRELA ÁTRIA (G12), FPS CERTERO (G13), JADEÍTE 11 (G14), LG ORO (G15), LG PRISMA (G16), LG CROMO (G17), LG SUPRA (G18), MARFIM (G19), MIRANTE (G20), ORS 1401 (G21), ORS 1402 (G22), ORS 1403 (G23), ORS 1405 (G24), evaluated in nine growing environments: Environment I and II (season I and season II) Cachoeira do Sul-RS, season I (1st half of June) and season II (2nd half of June), environment III and IV (season I and season II) Cruz Alta-RS, season I (1st half of June) and season II (2nd half of June), environment (V) Passo Fundo-RS, environment (VI) Santo Augusto-RS, environment (VII) São Gabriel-RS, environment (VIII) São Luiz Gonzaga-RS, environment (IX) Vacaria-RS. 


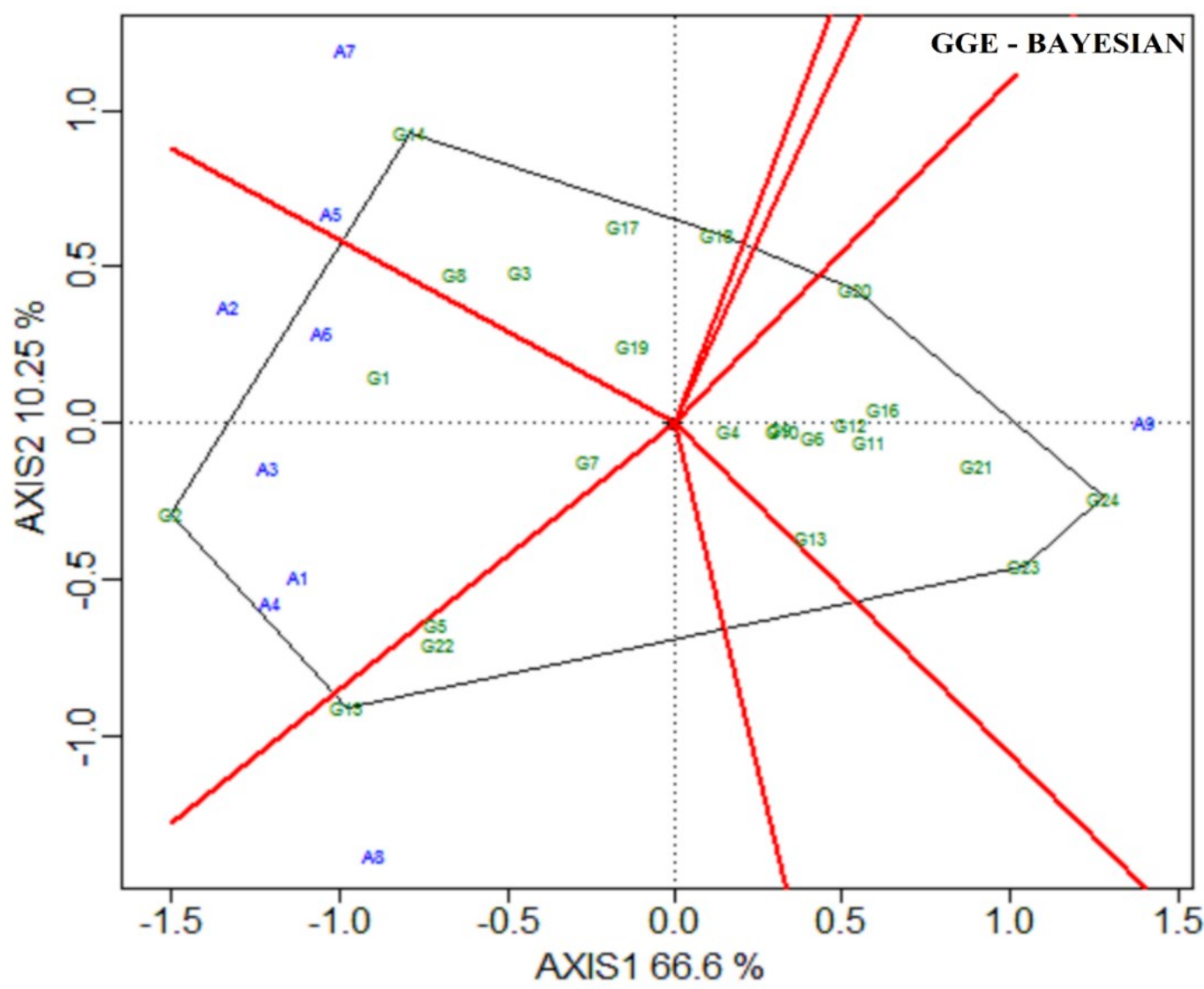

Figure 7. Genotype and Genotypes by Environments interaction (GGE) based on Bayesian models (MCMC): Ametista (G1), BRS 327 (G2), BRS 331 (G3), BRS MARCANTE (G4), BRS PARRUDO (G5), BRS REPONTE (G6), CD 123 (G7), CD 1440 (G8), CD 1550 (G9), CELEBRA (G10), ESPORÃO (G11), ESTRELA ÁTRIA (G12), FPS CERTERO (G13), JADEÍTE 11 (G14), LG ORO (G15), LG PRISMA (G16), LG CROMO (G17), LG SUPRA (G18), MARFIM (G19), MIRANTE (G20), ORS 1401 (G21), ORS 1402 (G22), ORS 1403 (G23), ORS 1405 (G24), evaluated in nine growing environments: Environment I and II (season I and season II) Cachoeira do Sul-RS, season I (1st half of June) and season II (2nd half of June), environment III and IV (season I and season II) Cruz Alta-RS, season I (1st half of June) and season II (2nd half of June), environment (V) Passo Fundo-RS, environment (VI) Santo Augusto-RS, environment (VII) São Gabriel-RS, environment (VIII) São Luiz Gonzaga-RS, environment (IX) Vacaria-RS.

\section{Contrast of fixed linear (GLM) mixed linear (MIXED) and bayesian (MCMC) models for Additive Main effects and Multiplicative Interaction - AMMI}

When analyzing the contrasts of the fixed linear, mixed, and bayesian models, we notice the following associations in the variable higher grain yield averages independent of the model used: ORS 1402 (G22), LG Oro (G15), however the average yield compared with the bayesian model changes the ranking, that is, genotypes that were not so successful increase their position in relation to the average of the experiment, and this is related to the bayesian model, as it increases the probability of the event happening (Figure 7).
The genotypes that showed average grain yield above the general average of the experiment, in favorable environments, that is, that are similar between the models: BRS 327 (G2), Jadeíte 11 (G14), however the similarity between the mixed and bayesian model is among the genotypes: BRS 327 (G2), Jadeíte 11 (G14), ORS 1405 (G24), that is, the increase of the genotype (G24). Regarding the stability of the genotypes, the most stable and with similarity between the GLM and MIXED models, is only the CD 1440 (G8) genotype that also had similarity between the GLM and BEYSEAN models, the Jadeíte 11 (G14) genotype. The genotypes with an average higher than the general average of the experiment and with stability and similarity between the MIXED and 
BEYSEAN models the genotype Marfim (G19). There was also similarity in the CD 1440 (G8), Marfim (G19) genotypes, in the fixed and mixed linear model.

The environments that showed significance (positive score) between the three models are: Cachoeira do Sul, second season (II) and São Gabriel - RS (VII: E7), however between the GLM and BEYSEAN models, there is similarity between: Cachoeira do Sul, second season (II), São Gabriel-RS (VII: E7), São Luiz Gonzaga-RS (VIII: E8), and between the MIXED and BEYSEAN models the similarity is between the environments: Cachoeira do Sul-RS, second season (II: E2), Passo Fundo-RS (V: E5), Santo Augusto-RS (VI: E6), and São Gabriel-RS (VII: E7). The unfavorable environments in common in the BEYSEAN and MIXED models are only the Vacaria-RS (IX: E9) environment, the similarity applied in the GLM and MIXED models is for the environments: Cachoeira do Sul-RS (I: E1) and Cruz Alta- RS, second season (IV: E4). Genotypes adapted to the favorable environment are positioned in the positive quadrant. The genotypes in common in the models being that by similarity between MIXED and GLM models, are LG Supra (G18), Jadeíte 11 (G14), ORS 1405 (G24) genotypes, there is also similarity between the genotypes in the MIXED and BEYSEAN models, LG Cromo (G17), Marfim (G19) and CD 1440 (G8). The genotypes that were not favorable to common environments: Esporão (G11).

\section{Contrast of fixed linear (GLM) mixed linear (MIXED) and bayesian (MCMC) models for Genotype and Genotypes by Environments interaction (GGE)}

Analyzing the contrast between the models (fixed, mixed, and Bayesian), we obtained the following correlations. The highest average grain yield of the genotypes in common in the two models mentioned were: ORS 1402 (G22), LG Oro (G15), Jadeíte 11 (G14). The genotypes that presented grain yield averages higher than the general average of the experiment in favorable environments are the genotypes to the right of the vertical line in the positive quadrant, which are in common: JADEÍTE 11 (G14), MARFIM (G19), LG CROMO (G17), ORS 1405 (G24), CD 1440 (G8), LG SUPRA (G18), MIRANTE (G20), BRS 327 (G2). The model still presents the stability of the genotypes, which is specified in the horizontal line of (3). The most stable genotype is MARFIM (G19). The environments that showed significance have a positive score, which were the following environments: Cachoeira do Sul, season I (I: E1), Cachoeira do Sul, season II (II: E2), Cruz Alta - RS, season I (III: E3), Cruz Alta - RS, season II (IV: E4), Passo Fundo - RS (V: E5), Santo Augusto - RS (VI: E6), São Gabriel - RS (VII: E7), São Luiz Gonzaga - RS (VIII: E8). The environments considered unfavorable are those with a negative score, only the Vacaria - RS environment (IX: E9).

\section{Conclusion}

Estimates of variance components and genetic parameters for wheat grain yield in the state of Rio Grande do Sul are expressed by $15 \%$ due to the inherent genetic effects of selecting the best genotype.

The growing environments Vacaria - RS, São Gabriel - RS and Cachoeira do Sul - RS Season II revealed the greatest genetic contributions to maximize wheat grain yield regardless of the crop season.

The mixed linear model allows the formation of a macroenvironment composed by the São Gabriel - RS and São Luiz Gonzaga - RS environments.

Regardless of the model used, the highest grain yields were obtained through the ORS 1402, LG Oro, and Jadeíte 11 genotypes.

\section{References}

CARVALHO, F.I.F.de; LORENCETTI, C.; MARCHIORO, V.S.; SILVA, S.A. Condução de populações no melhoramento genético de plantas. Pelotas: Universidade Federal de Pelotas, 2008. 
CRUZ, C.D. 2013. GENES - a software package for analysis in experimental statistics and quantitative genetics. Acta Scientiarum. v.35, n.3, p.271-276.

DUARTE, J.B.; VENCOVSKY, R. 1999. Interação genótipos x ambientes: uma introdução à análise AMMI. Ribeirão Preto: Sociedade Brasileira de Genética, 60p.

EBERHART, S.A.T.; RUSSELL, W.A. 1966. Stabilityparameters for comparingvarieties. Cropscience, v. 6, n. 1, p. 36-40.

GAUCH, H.G.; ZOBEL, R.W. 1996. AMMI analysis in yield trials. KANG, M.S.; GAUCH, H.G. (Ed) Genotype by environment interaction.

MARIOTTI, J.A.; OYARZABAL, E.S.; OSA, J.M.; BULACIO, A.N.R.; ALMADA, G.H. 1976. Análisis de estabilidad y adaptabilidad de genotipos de cana de azúcar. I. Interacciones dentro de unlocalidad experimental. Revista Agronómica del Noroeste Argentino, San Miguel de Tucumán, v.13, n.14, p.105-127, ene.

NASCIMENTO, M.; FERREIRA, A.; FERRÃO, R.G.; CAMPANA, A.C.M.; BHERING, L.L.; CRUZ, C.D.; FERRÃO, M.A.G.; FONSECA, A.F.A. 2010. Adaptabilidade e estabilidade via regressão não paramétrica em genótipos de café. Pesquisa Agropecuária Brasileira, v. 45, n. 1, p. 41-48.

PEREIRA, G.A.M.; MACIEL，J.C.; SANTOS, J.B.; REIS, R.F.; FERREIRA, E.A. 2017. Interferência de plantas daninhas no crescimento da cultura do trigo. Journal of neotropical agriculture, v. 4, n. 3, p. 23-29.

R DEVELOPMENT CORE TEAM. 2015. R: A language and environment for statistical computing. R Foundation for Statistical Computing, Vienna.

RAMALHO, M.A.P.; FERREIRA, D.F.; OLIVEIRA, A.C. 2000. Experimentação em genética e melhoramento de plantas. Lavras: UFLA.

RCBPTT - Reunião da Comissão Brasileira de Pesquisa de Trigo e Triticale, 2., 2011, Passo Fundo. Informações técnicas para a safra 2012: trigo e triticale. Passo Fundo: Comissão Brasileira de Pesquisa de Trigo e Triticale: Embrapa Trigo: Embrapa Transferência de Tecnologia, 2011. p. 211.

RESENDE, M.D.V. Software SELEGEN-REML/BLUP: sistema estatístico e seleção genética computadorizada via modelos lineares mistos. Colombo: Embrapa Florestas, 2007. 359p

RIBEIRO, N.D.; ANTUNES, I.F.; SOUZA, J.F.de.; POERSCH, N.L. 2008. Adaptação e estabilidade de produção de cultivares e linhagens-elite de feijão no Estado do Rio Grande do Sul. Ciência Rural, v. 38, n. 9, p. 2434-2440.

SANTOS, L.A.; PINTO, C.C.; SZARESKI, V.J.; CARVALHO, I.R.; KOCH, F.; PIMENTEL, J.R.; TROYJACK, C.; DUBAL, I.; REOLON, F.; ROSA, T.C.; PEDO, T.; MARTINAZZO, E.G.; MORAES, D. M.; SCHUCH, L.O.B.; VILLELA, F.A.; AUMONDE, T.Z. 2018. Respiratory activity and physiological performance of maize seeds classified according to their shapes and sizes. Australian Journal of Crop Science, v. 12, n. 12, p. 1882.

SILVA, R.R.; BENIN, G. 2012. Análises Biplot: conceitos, interpretações e aplicações. Ciência Rural, v. 42, n. 8, p. 1404-1412. 
STATISTICAL ANALYSIS SYSTEM. SAS Institute Inc. 2002-2003. Statistical analysis system.

Release 9.1. (Software). Cary. USA.SZARESKI, V.J.; CARVALHO, I.R.; KEHL, K.; LEVIEN, A.M.; NARDINO, M.; DEMARI, G.; LAUTENCHLEGER, F.; SOUZA, V.Q.; PEDO, T.; AUMONDE, T.Z. 2017. Univariate, multivariate techniques and mixed models applied to the adaptability and stability of wheat in the Rio Grande do Sul State. Genetics and Molecular Research, v. 16, n. 3.

WOYANN, L.G.; BENIN, G.; STORCK, L.; TREVIZAN, D.M.; MENEGUZZI, C.; MARCHIORO, V.S.; TONATTO, M.; MADUREIRA, A. 2017. Estimation of missing values affects important aspects of GGE biplot analysis. Crop Science, v. 57, n. 1, p. 40-52.

YAN, W. 2011. GGE biplot vs. AMMI graphs for genotype-by-environment data analysis. Journal of the Indian Society of Agricultural Statistics, v.65, n.2, p.181-193.

YAN, W.; HUNT, L.A.; SHENG, Q.; SZLAVNICS, Z. 2000. Cultivar evaluation and megaenvironment investigation based on the GGE biplot. Crop science, v. 40, n. 3, p. 597-605.

YAN, W.; KANG, M.S. 2003. GGE biplot analysis: a graphical tool for breeders, geneticists, and agronomists. Flórida: Boca Raton. 286p.

YAN, W.; KANG, M.S.; MA, B.; WOODS, S.; CORNELIUS, P.L. 2007. GGE biplot vs. AMMI analysis of genotype-by-environment data. Crop science, v. 47, n. 2, p. 643-653.

ZOBEL, R.W.; WRIGHT, M.J.; GAUCH, H.G. 1988. Statistical analysis of a yield trial. Agronomy journal, v. 80, n. 3, p. 388-393. 